\title{
TGF- $\beta 1-$ Induced Glomerular Disorder Is Associated with Impaired Concentrating Ability Mimicking Primary Glomerular Disease with Renal Failure in Man
}

\author{
Søren Krag, Ruth Østerby, Qing Chai, Camilla Birch Nielsen, \\ Cedric Hermans, and Lise Wogensen
}

The Research Laboratory for Biochemical Pathology (SK, QC, CBN, LW) and the Laboratory for Electronmicroscopy $(R \varnothing)$, The Institute of Experimental Clinical Research, Aarhus Kommunehospital, Aarhus, Denmark; and Industrial Toxicology and Occupational Medicine Unit $(\mathrm{CH})$, The Faculty of Medicine, The Catholic University of Louvain, Brussels, Belgium

SUMMARY: Transforming growth factor- $\beta 1$ (TGF- $\beta 1$ ) may play a major role in the pathogenesis of glomerulopathy and end-stage renal disease (ESRD). The aim of this study was to explore the functional consequences of localized overproduction of TGF- $\beta 1$ in relation to glomerular ultrastructure and the composition of the extracellular matrix (ECM) in the inner medulla. We used a transgenic mouse with overexpression of TGF- $\beta 1$ targeted to the juxtaglomerular apparatus (JGA) by the Ren- $1^{\mathrm{C}}$ promoter. The kidney function was evaluated using urine production and metabolite excretion over a 24-hour period, glomerular filtration rate (GFR), and concentrating ability. The glomerular structure was analyzed in terms of volume, ie, the volume of the mesangium per glomerulus ( $\mathrm{Vv}$ [mes/glom]) and the volume of the matrix per glomerulus ( $\mathrm{Vv}$ [matrix/glom]), ECM per glomerulus, the area of the filtration surface, and the thickness of the peripheral basement membrane (PBM). Immunohistochemistry or in situ hybridization was used to examine the expression of aquaporin 2 (AQP2), plasminogen activator inhibitor-1 (PAI-1), and the composition of the ECM in the inner medulla. The mice exhibited polyuria, reduced concentrating ability, decreased GFR, and albuminuria paralleled by increased glomerular volume, with increased volume of ECM, decreased filtration surface, and thickening of the PBM being detectable between 1 and 2 months of age. The deposition of glomerular ECM was accompanied by increased levels of PAI-1. As estimated by excretion of Clara cell protein-1 (CC16) and lysozyme, tubular damage occurred only in older mice. Collagen Type I was deposited in the inner medulla in the presence of normal AQP2-expression in the collecting ducts. This study reached the following conclusions: (a) TGF- $\beta 1$ reduces the GFR and the glomerular filtration surface, (b) TGF- $\beta 1$ induces albuminuria in association with widening of the PBM, (c) expansion of the mesangial volume seems to precede the widening of the PBM, (d) TGF- $\beta 1$-induced accumulation of glomerular ECM is partly explained by increased PAI-1 expression, (e) Decreased concentrating ability and polyuria caused by accumulation of ECM in the inner medulla may be an early marker of glomerular diseases associated with increased expression of TGF- $\beta 1$ in man. (Lab Invest 2000, 80:1855-1868).

$D$ iabetic nephropathy and glomerulonephritis are worldwide the most common diseases leading to glomerulopathy and end-stage renal disease (ESRD) (Maisonneuve et al, 2000). Glomerulopathy may appear as thickening of the peripheral basement membrane (PBM), extensive deposition of mesangial

\section{Received July 24, 2000.}

Soren Krag was the recipient of a scholarship from the Danish Medical Research Council (No. 9701174). The project was supported by the Danish Diabetes Association, the Danish Medical Research Council (Grants No. 9601759, 9802621, and 9600822), Aarhus University-Novo Nordisk Center for Research in Growth and Regeneration, the Novo Nordisk Foundation, and The Institute of Experimental Clinical Research, Aarhus University, Aarhus, Denmark.

Address reprint requests to: Associate Professor Lise Wogensen Bach, The Research Laboratory for Biochemical Pathology, The Institute of Experimental Clinical Research, Aarhus University, Aarhus Kommunehospital 44-Noerrebrogade, DK-8000 Aarhus C, Denmark. Fax: 45894921 50; E-mail:lwb@biobase.dk extracellular matrix (ECM), and eventually, loss of capillaries, whereas ESRD is characterized by reduced glomerular filtration rate (GFR) and impaired concentrating ability (Bruijn et al, 1994; Conte et al, 1985). The progression of glomerular diseases to glomerulopathy and to ESRD may be mediated by autocrine or paracrine production of different growth factors such as transforming growth factor- $\beta 1$ (TGF$\beta 1$ ) (Bruijn et al, 1994; Fine et al, 1998). The renal content of TGF- $\beta 1$ is elevated in both the acute and the chronic phase of many human kidney diseases such as diabetic nephropathy and glomerulonephritis, and in animal models of these diseases (Bódi et al, 1997; Coimbra et al, 1991; Iwano et al, 1996; Niemir et al, 1995; Okuda et al, 1990; Shankland et al, 1994; Sharma and Ziyadeh 1994; Sharma et al, 1997; Yamamoto et al, 1993, 1996, 1994; Yang et al, 1995; Yoshioka et al, 1993). It is a common belief that if the amount of glomerular TGF- $\beta 1$ in a situation with 
reversible glomerular damage increases above a threshold level, or if the TGF- $\beta 1$ expression is prolonged, a progression to irreversible glomerulopathy may be provoked (Border and Noble, 1997; Border and Ruoslahti, 1992). This hypothesis is supported by the observation of a TGF- $\beta 1$-dose-effect on the progression of kidney fibrosis in antithymocyte-induced glomerulonephritis (Yamamoto et al, 1994) and a gene-dosis effect in transgenic mice expressing TGF- $\beta 1$ in the kidney under control of the Ren- $1^{c}$ promoter (Wogensen et al, 1999).

ESRD is a major health problem all over the world. A detailed knowledge about the pathogenetic mechanisms leading to glomerulopathy and ESRD is pivotal for implementation of new preventive-treatment strategies. No doubt, several factors contribute to the pathogenesis of glomerulopathy and ESRD. Thus, to study a single factor in detail, the transgenic approach is especially useful. Therefore, the aim of the present project was to explore the functional consequences of localized overproduction of TGF- $\beta 1$ in relation to the glomerular ultrastructure and the composition of the ECM in the inner medulla using our transgenic mouse with overexpression of TGF- $\beta 1$ in the juxtaglomerular apparatus (JGA) (Wogensen et al, 1999).

\section{Results}

\section{Body Weight, Diurnal Water and Food Consumption, and Urine Production}

At all examined ages the body weight (BW) of the transgenic mice was statistically significantly lower than the BW of the nontransgenic littermates, albeit the food intake in the two groups of animals was the same at 1 to 3 months of age. Also, 4- and 5-monthold transgenic mice consumed significantly more food than the control animals (Table 1). The transgenic mice drank two to three times more water than the nontransgenic controls, and from the age of 6 weeks, their 24-hour urine production was higher compared with that of nontransgenic controls (Table 1). The correlation coefficients between diurnal water intake and diuresis in transgenic and nontransgenic mice were $r=0.59(p<0.001)$ and $r=0.17(p>0.05)$, respectively.

\section{Urine Metabolite Excretion in 24-Hour Period}

One-month-old nontransgenic mice excreted more $\mathrm{Na}^{+}(158 \pm 17 \mu \mathrm{mol} / 24$ hours, $n=6)$ than the transgenic animals $(108 \pm 14 \mu \mathrm{mol} / 24$ hours, $n=6)(p$ $<0.05$ ) (Fig. 1A). At 6 weeks of age the $\mathrm{Na}^{+}$excretion was similar in the two groups of mice, whereas older transgenic mice ( $>6 \mathrm{wk}$ ) excreted one-and-a-half to two times more $\mathrm{Na}^{+}$than the nontransgenic littermates, although this difference never reached statistical significance (Fig. 1A). The 24-hour excretion of $\mathrm{K}^{+}$was similar in the two groups of mice at each tested age (data not shown).

To evaluate the integrity of the glomerular filtration barrier, we measured the urinary excretion of albumin. At 4 and 6 weeks of age, the 24-hour urinary albumin excretion was similar in the two groups of mice (Fig. 1B). However, from 2 months of age, it was significantly higher in the transgenic mice compared with that in the nontransgenic littermates (Fig. 1B). The 24-hour urine albumin excretion of the nontransgenic mice remained steady from 6 weeks to 5 months of age $(0.9 \pm 0.26, n=8$, and $1.2 \pm 0.5 \mu \mathrm{g} / 24 \mathrm{hr}, n=6$, respectively) ( $r=0.2, p>0.05)$, whereas the albumin excretion in the transgenic mice increased progressively from $2.0 \pm 0.43 \mu \mathrm{g} / 24$ hours $(n=6)$ at the age of 6 weeks to $21.25 \pm 5.68 \mu \mathrm{g} / 24$ hours $(n=6)$ at 5 months of age (Fig. 1B) $(r=0.70, p<0.01)$.

\section{Parameters of Tubular Function}

To exclude the possibility that the albuminuria was caused by decreased reabsorption as a result of functional abnormalities in the proximal tubules, we measured the 24-hour urine secretion of Clara Cell protein-1 (CC16) and lysozyme. In 4- and 6-week-old nontransgenic mice, the CC16 secretion was $62 \pm$ $15.9 \mathrm{ng} / 24$ hours $(n=5)$ and $21 \pm 4.7 \mathrm{ng} / 24$ hours $(n$ $=8$ ), respectively, compared with $25.4 \pm 2.8 \mathrm{ng} / 24$ hours $(n=6)$ and $8.0 \pm 2.3 \mathrm{ng} / 24$ hours $(n=6)$, respectively, in transgenic littermates $(p<0.01$ and $p$ $<0.05$ ) (Fig. 1C). At 2 and 3 months of age, the 24-hour secretion of CC16 was similar in the two groups of mice, whereas in 4- and 5-month-old transgenic mice, the CC16 secretion was increased to 842 $\pm 422 \mathrm{ng} / 24$ hours $(n=6)$ and $663 \pm 225 \mathrm{ng} / 24$ hours $(n=6)$, respectively, compared with $16 \pm 4.9 \mathrm{ng} / 24$ hours $(n=6)$ and $21 \pm 10.6 \mathrm{ng} / 24$ hours $(n=6)$ in nontransgenic littermates $(p<0.01$ in both age groups) (Fig. 1C). The 24-hour lysozyme secretion in 1-month-old nontransgenic mice was $2.2 \pm 0.49$ $\mathrm{ng} / 24$ hours $(n=5)$ compared with $0.8 \pm 0.17 \mathrm{ng} / 24$ hours in transgenic littermates $(n=6)(p<0.02)$, whereas it was similar in the two groups of mice at 6 , 8 , and 12 weeks of age (Fig. 1D). As for CC16, the 24-hour lysozyme secretion was increased in 4- and 5 -month-old transgenic mice $(10.0 \pm 5.0 \mathrm{ng} / 24$ hours, $n=6$, and $16.0 \pm 7.0 \mathrm{ng} / 24$ hours, $n=6$, respectively) compared with that in nontransgenic littermates $(0.61$ $\pm 0.09 \mathrm{ng} / 24$ hours, $n=6$, and $0.49 \pm 0.17 \mathrm{ng} / 24$ hours, $n=6$, respectively) ( $p<0.01$ in both age groups) (Fig. 1D). The correlation between the secretion of CC16 and lysozyme was $r=0.78(p<0.01)$ in the transgenic mice and $r=0.60(p<0.01)$ in nontransgenic animals, documenting that lysozyme, too, can be used as an indicator of functional abnormalities in the proximal tubules.

\section{Parameters of Kidney Function}

The plasma creatinine level at each tested age was about $20 \mu \mathrm{mol} / \mathrm{l}$ in the nontransgenic animals (Fig. 2A). Four and six-week-old transgenic mice exhibited plasma creatinine levels comparable to those of the nontransgenic mice. In contrast, the plasma creatine levels increased to $29.0 \pm 2.9 \mu \mathrm{mol} / \mathrm{l}(n=6)$ and to $28.3 \pm 2.6 \mu \mathrm{mol} / \mathrm{l}(n=6)$ in 2- and 3-month-old transgenic mice, respectively $(p<0.05$ vs age- 


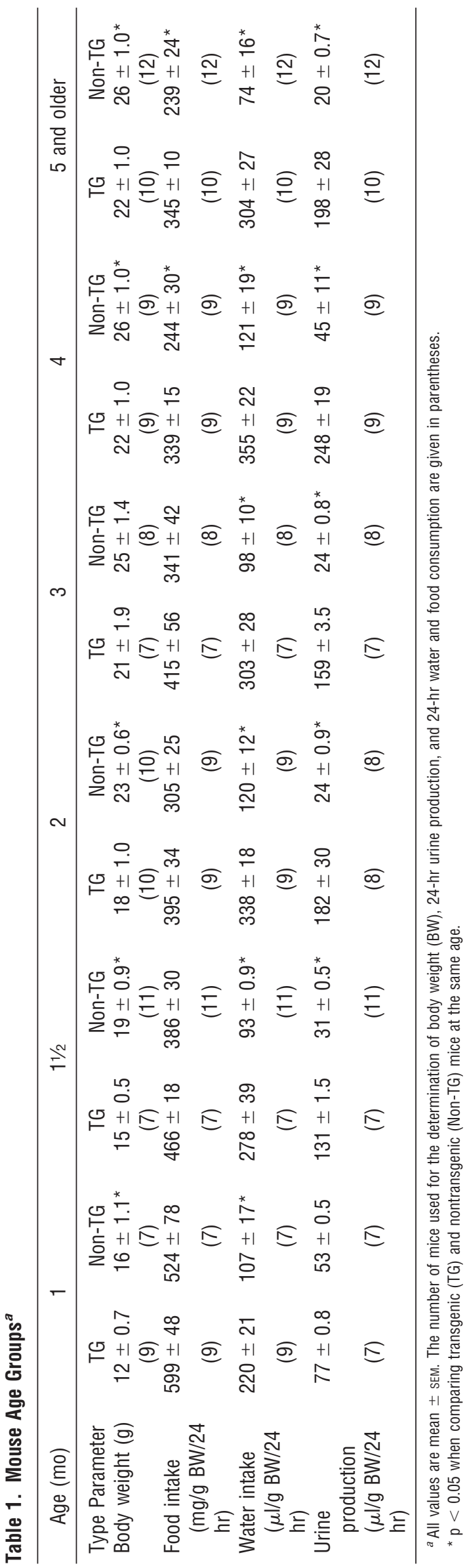

matched control animals), and to $39.0 \pm 5.6 \mu \mathrm{mol} / \mathrm{l}(n$ $=6)$ and $40.3 \pm 5.6 \mu \mathrm{mol} / \mathrm{l}(n=6)$ in the 4 - and 5 -month-old transgenic mice, respectively $(p<0.05$ vs nontransgenic littermates) (Fig. 2A). There was a significant correlation between age and the plasma concentration of creatinine in the transgenic mice $(r=$ $0.49, p<0.01$ ).

The plasma concentration of blood urea nitrogen $(B U N)$ in the transgenic mice was significantly increased at all examined ages compared with that of age-matched nontransgenic mice (Fig. 2B). In the transgenic mice, the circulatory levels of BUN exhibited a progressive increase during the observation period $(r=0.4, p<0.05)$, whereas it was stable in the nontransgenic mice $(r=0.08, p=0.66)$ (Fig. 2B).

To verify that the increased plasma concentrations of creatinine and BUN were due to a decreased GFR and not to disturbances in protein and muscle metabolism, we performed a chromium ${ }^{51}$-labeled EDTA $\left({ }^{51} \mathrm{Cr}\right.$-EDTA) clearance. Three-month-old transgenic mice had a significantly lower ${ }^{51} \mathrm{Cr}$-EDTA clearance $\left(15.5 \pm 2.48 \mathrm{ml} /\right.$ minutes $\left./ \mathrm{m}^{2}, n=7\right)$ compared with that of the nontransgenic mice $(33.6 \pm 3.34 \mathrm{ml} /$ minutes $\left./ \mathrm{m}^{2}, n=5\right)(p<0.01)$ (Fig. $\left.2 \mathrm{C}\right)$. The ${ }^{51} \mathrm{Cr}$-EDTA experiment revealed that the distribution volume of ${ }^{51} \mathrm{Cr}$-EDTA was $31 \pm 0.93 \%$ of the BW in the transgenic mice $(n=7)$ and $26 \pm 2.60 \%$ in the nontransgenic littermates $(n=5)(p>0.05)$ (Fig. 2D), indicating that major disturbances in the extracellular volume in the transgenic mice were absent. Interestingly, the hematocrit was $35 \pm 1.1 \%$ in the transgenic mice $(n=$ 7) compared with $52 \pm 0.8 \%$ in the nontransgenic mice $(n=5)(p<0.01)$.

The plasma $\mathrm{Na}^{+}$concentration was slightly increased in the transgenic mice; it was statistically significant at 3 and 5 months of age when compared with that of the nontransgenic littermates (Fig. 2E). This may be explained by the presence of moderately elevated plasma concentrations of aldosterone in the transgenic mice, which were statistically significant at 3 months of age (Fig. 2F). The plasma $\mathrm{K}^{+}$concentration was similar in the two groups of mice at any tested age (data not shown).

\section{Renal Water Handling}

The transgenic mice exhibited an extensive polyuria, suggesting that they suffered from abnormalities in water handling. Osmotic diuresis was excluded because the urine was clearly hypotonic in the group of 3-month-old transgenic mice $(791 \pm 130 \mathrm{mOsm}, n=$ 8) compared with that in age-matched nontransgenic littermates (2945 \pm 79 mOsm, $n=13)(p<0.05)$ (Fig. $3)$. In addition, the transgenic mice were not able to concentrate their urine as efficiently as the nontransgenic littermates. Water deprivation for 12 hours led to an increase $(\Delta)$ in urine osmolarity of only $168 \pm 92$ mOsm in the transgenic mice $(n=8)$ compared with $887 \pm 230 \mathrm{mOsm}$ in the nontransgenic animals $(n=$ 13) $(p<0.05)$ (Fig. 3). Already, at 6 weeks of age, the transgenic animals exhibited a lower urine osmolarity (1418 $\pm 152 \mathrm{mOsm}, n=6$ ) compared with that of the 

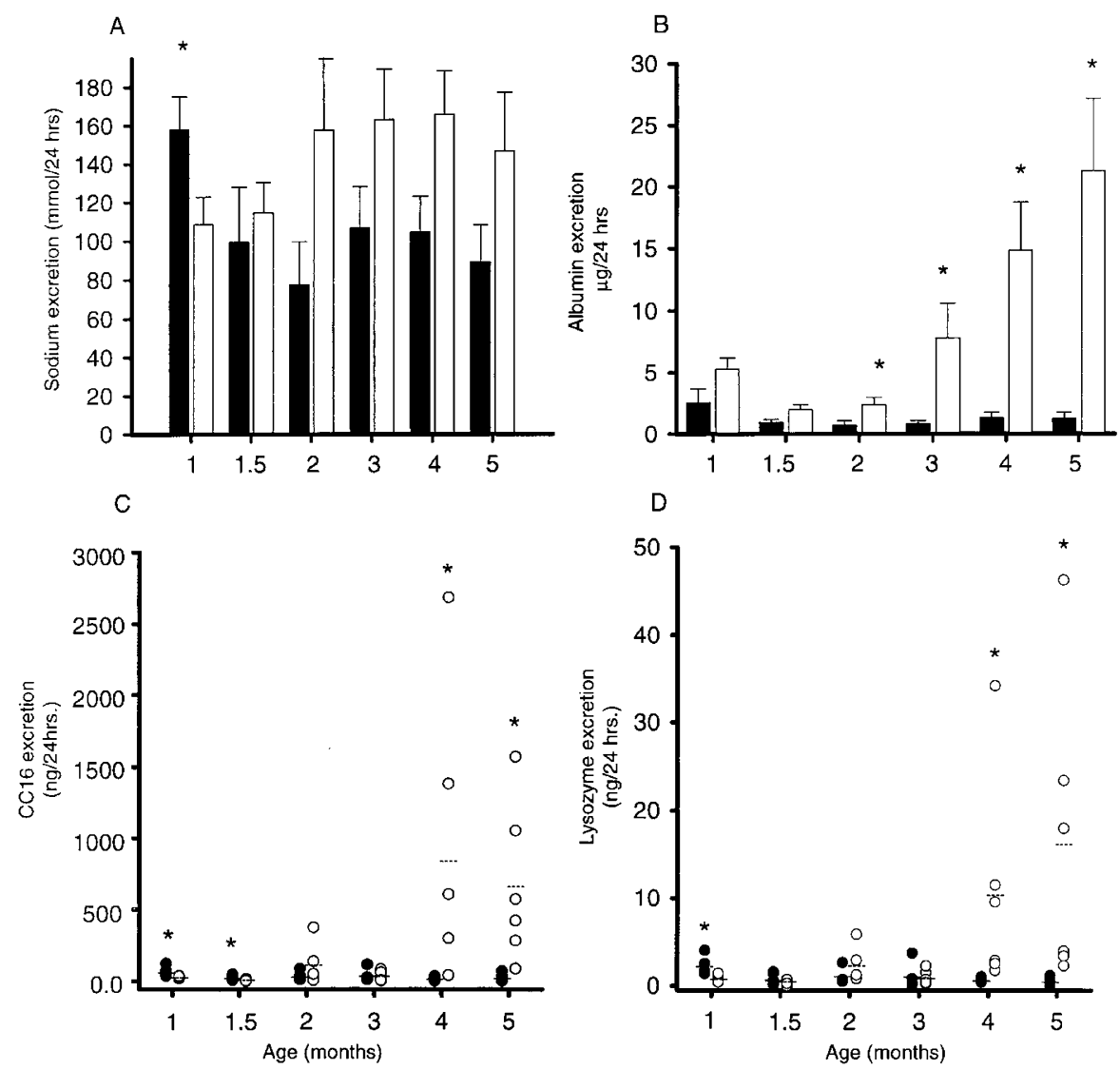

Figure 1.

Urine excretion (per $24 \mathrm{hr}$ ) of $\mathrm{Na}^{+}(A)$, albumin $(B)$, Clara cell protein-1 (CC16) $(C)$, and lysozyme $(D)$ in transgenic $(\bigcirc / \square)$ and nontransgenic $(\mathbf{\square})$ mice at different ages. The number of mice in each group is reported in Table 3 . Values are mean \pm SEM. ${ }^{*} p<0.05$.

nontransgenic controls (2287 \pm 259 mOsm, $n=2)$, and the increase $(\Delta)$ in urine osmolarity after 12 hours of water deprivation was $685 \pm 168 \mathrm{mOsm}$ in the transgenic mice $(n=6)$ compared with $1195 \pm 695$ mOsm in the nontransgenic animals $(n=2)$. (It was very difficult to collect enough urine from the young nontransgenic animals. This explains the low number of control mice). Another parameter for the urine concentrating ability is the free water clearance. At 3 months of age, four of six transgenic mice had a free water clearance of $-48.6 \pm 12.5 \mu \mathrm{l} /$ minutes $/ \mathrm{kg} \mathrm{BW}$, whereas two tested transgenic mice had a free water clearance of $-173 \pm 3 \mu \mathrm{l} /$ minutes $/ \mathrm{kg} \mathrm{BW}$, which is similar to that of the nontransgenic mice $(-171 \pm 12$ $\mu \mathrm{l} / \mathrm{minutes} / \mathrm{kg} \mathrm{BW})(n=4)$. The plasma osmolarity was $385 \pm 3.3 \mathrm{mOsm}$ in the transgenic mice $(n=6)$ and $392 \pm 25$ mOsm $(n=4)$ in the nontransgenic mice $(p$ $>$ 0.05). Aquaporin 2 (AQP2), the vasopressinsensitive water channel, has a pivotal role in the renal water handling (Fushimi et al, 1993). We found that the AQP2 water channels were located principally within the apical membrane of the epithelial cells lining the collecting ducts, because the immunofluorescence was distributed as an intense linear staining in 1-, 2-, and 3-month-old transgenic mice ( $n=1,3$, and 4, respectively) (Fig. 4A). One- and two-month-old nontransgenic mice ( $n=1$ and 2 , respectively) had the same AQP2-staining pattern as the transgenic mice, whereas in 3-month-old control mice $(n=4)$, the apical staining seemed to be reduced compared with that in the transgenic mice (Fig. 4B). In both groups of mice, the staining of AQP2 was seen exclusively in the collecting ducts. The hypotonic polyuria was not reversed by desmopressin (ddAVP) $(0.4 \mu \mathrm{g} / \mathrm{kg}$ BW, given after water deprivation for 12 hours) (Ma et al, 1998) because the urine osmolarity of the transgenic mice increased only from $854 \pm 33.5 \mathrm{mOsm}$ to $967 \pm$ $59.5 \mathrm{mOsm}(\Delta=113 \pm 93 \mathrm{mOsm}, n=2)$, whereas the increase was from $3291 \pm 642 \mathrm{mOsm}$ to $3826 \pm 173$ mOsm $(\Delta=535 \pm 124$ mOsm, $n=3)$ in the nontransgenic mice. We have previously shown that the inner part of the medulla in older transgenic mice is rich in collagen Type I deposits, whereas this collagen type is very rare in nontransgenic mice (Wogensen et al, 1999). We now report that, simultaneously with the progression of polyuria at 6 and 8 weeks of age, 3 of 6 and 9 of 10 transgenic mice, respectively, developed collagen Type I deposits in the inner medulla in contrast to 0 of 6 and 1 of 9 nontransgenic mice, respectively, $(p>0.05$ and $p=0.02)$ (Fisher's test) (data not shown). Collagen Type I deposits were absent in 4-week-old transgenic mice $(n=6)$. In situ hybridization demonstrated the presence of mRNA encoding for collagen Type $I$ in two out of three transgenic mice at 4,6 , and 8 weeks of age, but not in 
A

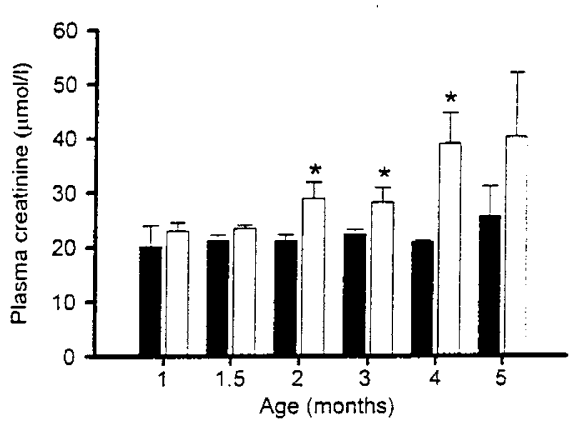

C

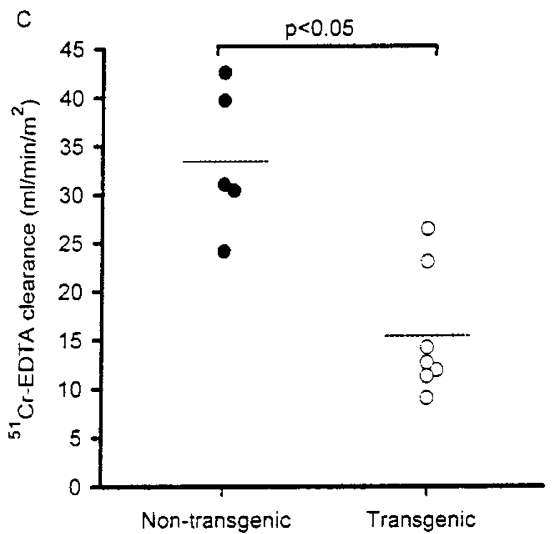

E

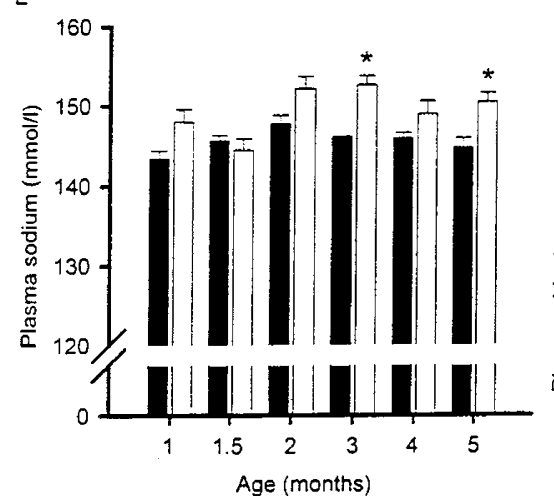

B
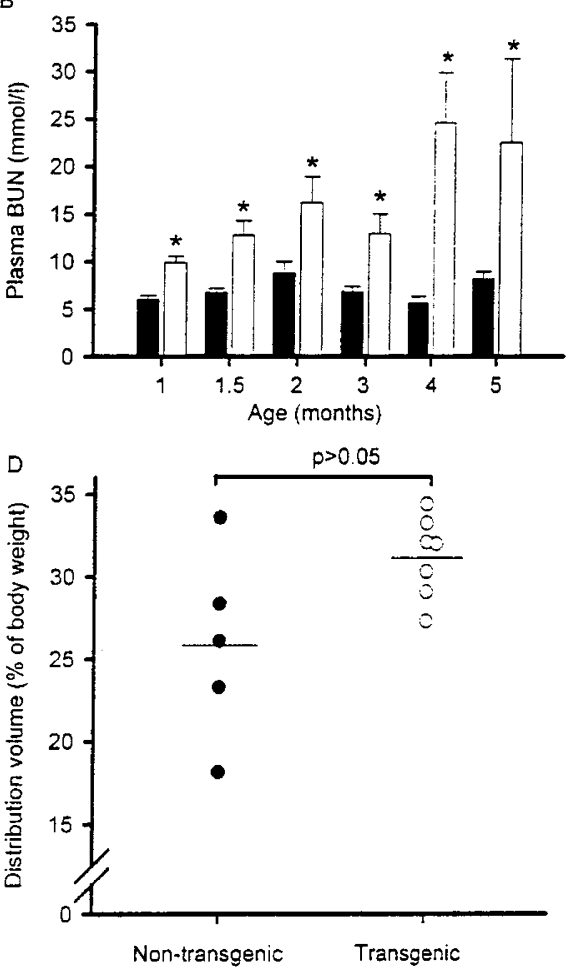

F

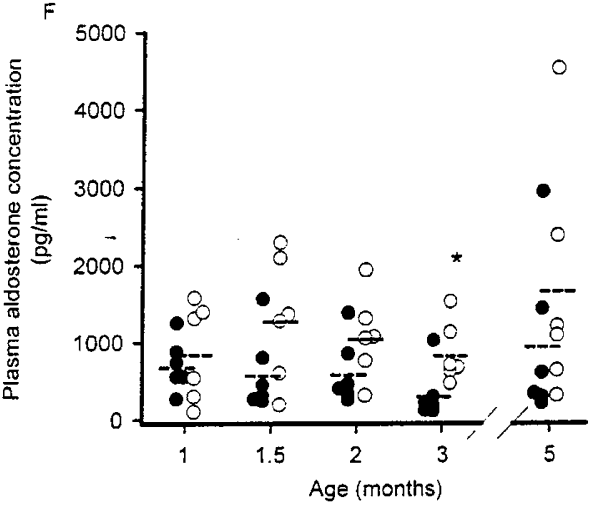

Figure 2.

Parameters of the glomerular filtration rate. The plasma concentrations of creatinine $(A)$, blood urea nitrogen $(B U N)(B), \mathrm{Na}^{+}(E)$, and aldosterone $(F)$ in transgenic $(\mathrm{O} / \square)$ and nontransgenic $(\mathbf{\square})$ mice at different ages. The number of mice in each group is reported in Table 3 . Values are mean \pm SEM. ${ }^{*} p<0.05$. ${ }^{51} \mathrm{Cr}-\mathrm{EDTA}$ clearance $(C)$ and distribution volume (extracellular volume) $(D)$ in 3-month-old transgenic $(n=7)(\circ)$ and nontransgenic $(\bullet)$ mice $(n=5)$.

any of the nontransgenic littermates $(n=3$ at each tested age) (Fig. 4, C and D). As evaluated by immunohistochemistry, the expression of collagen Types III and $\operatorname{IV}(\alpha 1$ and $\alpha 4)$ in the medullary interstitium was similar in the two groups of mice at each tested age (4, 6 , and 8 weeks of age, $n=3-6$ at each tested age in each group of mice), whereas collagen Type $\mathrm{V}$ was absent (data not shown). The expression of fibronectin in the inner medulla was increased only in transgenic mice older than 3 months of age (data not shown). When a subpopulation of the mice $(n=3$ in each group) was evaluated by in situ hybridization, the mRNA expression of collagen Types III $(\alpha 1)$ and IV $(\alpha 1)$ and fibronectin in the inner medullary area were higher in transgenic animals compared with that of nontransgenic mice at each tested age (data not shown).

\section{Quantitative Morphology}

To investigate which morphological changes in the glomeruli could account for the reduced GFR and the albuminuria, we performed quantitative ultramorphology. In the group of 3-month-old transgenic animals, the ultrastructural changes were so dramatic that a correct distinction between the PBM and the mesangium was impossible, and this inability to distinguish the two areas eventually hindered a valid quantitation of the selected parameters. Thus, only 1- and 2-month-old transgenic and nontransgenic animals ( $n=7$ at each tested age) were examined in detail.

The area of the peripheral capillary surface (the glomerular filtration surface) is the structural determinant of the GFR (Hirose et al, 1980). The area of the 


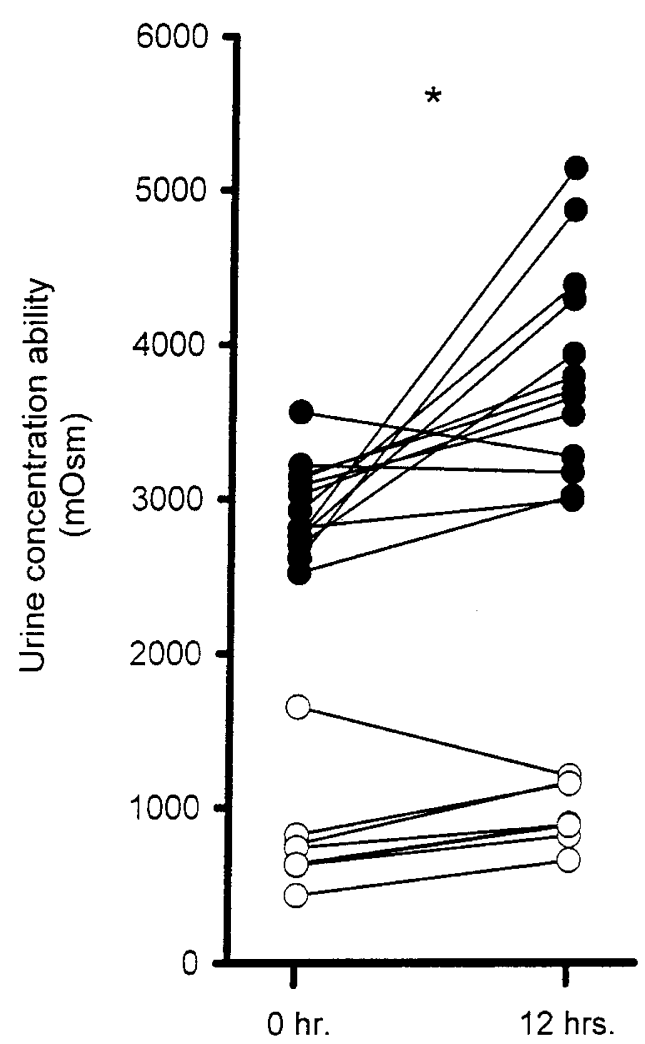

Figure 3.

Urine osmolarity and concentrating ability in 3-month-old transgenic $(\bigcirc)(n=$ $7)$ and nontransgenic $(\mathbf{O})$ mice $(n=13)$. Urine osmolarity was measured before $(0 \mathrm{hr})$ and after a thirst period of 12 hours. ${ }^{*} p<0.05$.

filtration surface was normal in the young transgenic mice but was almost halved at the age of 2 months (Table 2) $(p<0.0002)$. Part of this reduction was explained by a relative increase in the mesangialurinary interface (mes surface/tuft surface, \%) $(p<$ 0.0001) (Table 2). In 1-month-old transgenic mice, the mesangial fraction of the tuft surface was also increased, although to a lesser degree $(p<0.05)$ (Table 2).

An increase in the thickness of the PBM may be accompanied by albuminuria (Steffes et al, 1989). The thickness of the PBM in 4-week-old transgenic mice was normal, whereas it was markedly increased in the group of 2-month-old mice compared with that of nontransgenic littermates $(p<0.03)$ (Table 2).

The glomerular volume in 1-month-old transgenic mice was similar to that of age-matched controls, yet it was larger in 2-month-old transgenic mice compared with that of the nontransgenic animals $(p=$ 0.04) (Table 2). Expression of TGF- $\beta 1$ could affect the maturation of the glomeruli, but although the glomerular volume in 1-month-old transgenic mice seemed to vary more within individual kidneys than in the nontransgenic littermates, this difference was not statistically significant (Table 2). The increase in the glomerular volume was mainly caused by mesangial enlargement because the volume fraction of the mesangium ( $\left.\mathrm{V}_{\mathrm{v}}[\mathrm{mes} / \mathrm{glom}]\right)$ was higher in 2-month-old transgenic mice compared with that of age-matched controls ( $p<0.0002$ ) (Table 2 ), and this was partly due to an increased fraction of the mesangial matrix $\left(\mathrm{V}_{\mathrm{v}}\right.$ [matrix/glom]) $(p<0.003)$ (Table 2). Accordingly, the total amount of ECM per glomerulus (mesangial matrix and PBM volume fraction $\times V$ [glom]) was higher in 2-month-old transgenic mice than in nontransgenic littermates $(p<0.01)$ (Fig. 5). It should be noted that both the $\mathrm{Vv}$ (mes/glom) and the $\mathrm{Vv}$ (matrix/ glom) was higher in 1-month-old transgenic mice than in nontransgenic littermates $(p<0.04$ and $p<0.05)$ (Table 2). As mentioned above, this had no impact on glomerular size but increased the mesangial-urinary interface relative to the tuft surface (mes surface/tuft surface, \%).

The expansion of the total amount of ECM per glomerulus may partly be mediated by a decreased ECM breakdown. Inhibition of plasminogen activators by plasminogen-activator-inhibitor-1 (PAl-1), production of which is known to be stimulated by TGF- $\beta 1$, attenuates ECM degradation (Tomooka et al, 1992). Immunohistochemistry demonstrated that the PAI-1 content in the mesangium of 4- and 6-week-old transgenic mice ( $n=6$ in each group) was higher than that of the nontransgenic littermates $(n=6$ and $n=7)(p=$ 0.02 and $p=0.002$, respectively). In the group of 6 -week-old transgenic mice, increased amounts of $\mathrm{PAl}-1$ deposits were not only seen in the mesangium but also in the PBM ( $p=0.002)$ (Fig. 6). At 8 weeks of age, the PAl-1 expression was similar in the two groups of mice ( $n=7$ in each group) $(p>0.05)$.

\section{Discussion}

The progression of glomerular diseases to glomerulopathy and ESRD is associated with glomerular accumulation of ECM coupled with a significant reduction in the glomerular filtration surface, reduced GFR, and disturbances in renal water handling. These features are reproduced in the present model of TGF- $\beta 1$ induced kidney disease: (a) TGF- $\beta 1$ induced a reduction in the GFR associated with a decreased filtration surface that was caused by an increase in the fraction of mesangial matrix, and (b) the mice exhibited decreased concentrating ability and vasopressinresistant hyposomolar polyuria, most likely a result of intrinsic damage in the inner medulla.

In 1-month-old transgenic mice, the plasma concentration of creatinine was normal, whereas the circulatory level of BUN was increased, indicating a slightly decreased kidney function. By electromicroscopy we found an increased content of mesangial matrix in the glomerulus, whereas the thickness of the PBM was normal. The increase in glomerular ECM did not affect the 24-hour secretion of albumin.

In 2-month-old transgenic mice, the plasma concentrations of both creatinine and BUN were increased. Determination of GFR by a ${ }^{51} \mathrm{Cr}$-EDTA clearance experiment was hard to perform in young mice. However, we tested two 8-week-old transgenic mice and found GFR values of $15 \mathrm{ml} /$ minutes $/ \mathrm{m}^{2}$ and 18 $\mathrm{ml} / \mathrm{minutes} / \mathrm{m}^{2}$. The declining kidney function was accompanied by a further increase in the mesangial- 

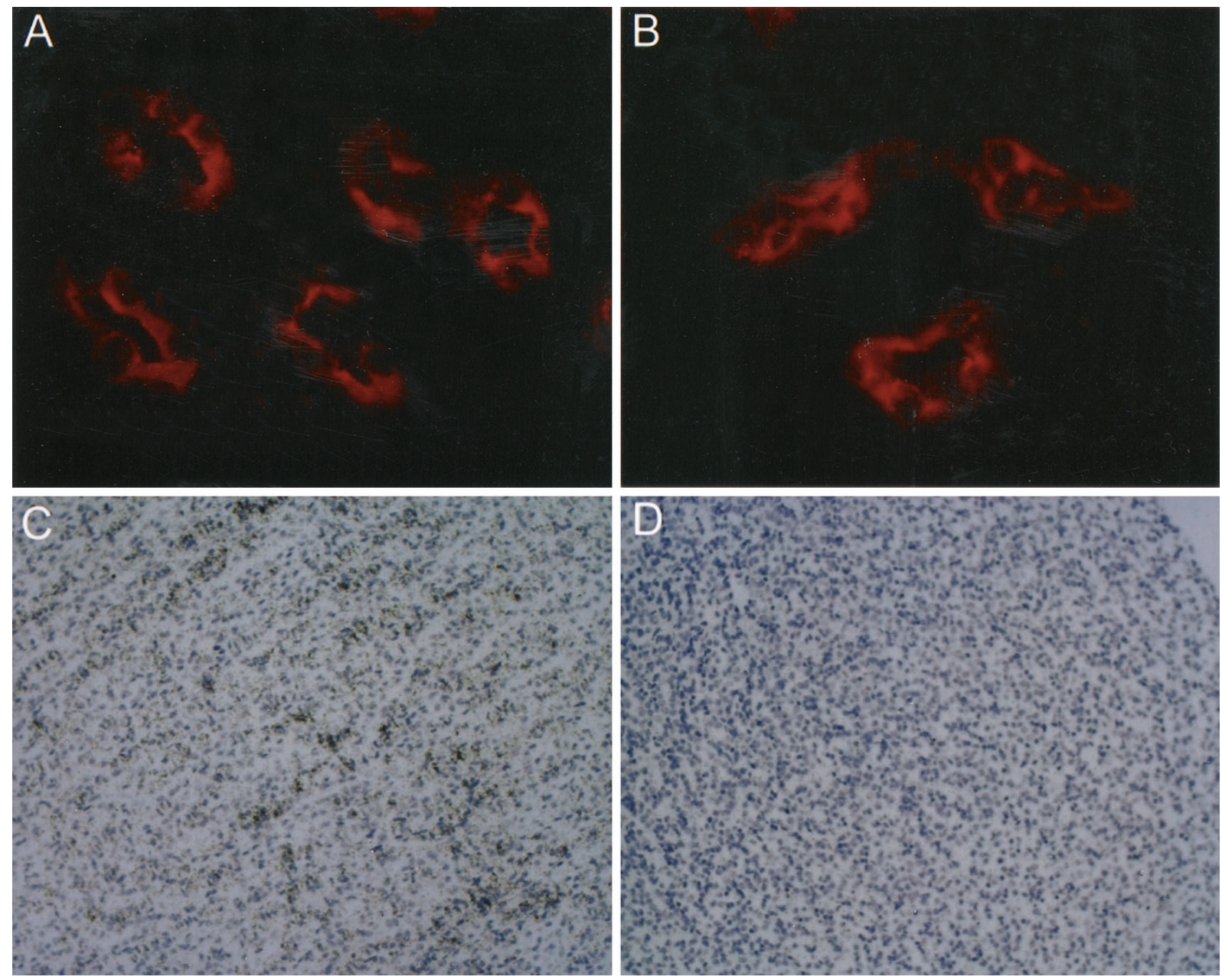

\section{Figure 4.}

The expression of aquaporin-2 (AQP-2) in the inner medulla of a 3-month-old transgenic $(A)$ and nontransgenic $(B)$ mouse $(\times 1000)$. In situ hybridization demonstrates the presence of RNA (black grains) coding for collagen Type I $(\alpha 1)$ in the inner medulla of a 2-month-old transgenic mouse $(C)(\times 400)$. An age-matched nontransgenic mouse has no collagen Type I $(\alpha 1)$ expression $(D)(\times 400)$.

urinary interface, which at this age was paralleled by a significant reduction in the filtration surface. These observations are in agreement with the presence of a strong correlation between GFR and the filtration surface in nephropathy, at least as investigated in diabetic nephropathy (Ellis et al, 1986; Østerby et al, 1988). At this age the changes in the glomerular tuft consisted also of a thickening of the PBM resulting in a statistically significant albuminuria. Thus, TGF- $\beta 1$ induces glomerulopathy and nephropathy. It should be considered, however, that some of the observed morphological changes may be due to indirect effects.

The mesangium, in association with the PBM, constitutes the filtration unit in the glomerulus. It is puzzling that a thick PBM can be a functional and effective barrier. On the other hand, marked mesangial expansion is uniformly associated with proteinuria (Steffes et al, 1989). It is likely that the structural and biochemical changes in the PBM in combination with increased amounts of mesangial ECM may explain the glomerular albuminuria that is evident in the transgenic mice at 2 months of age. Interestingly, it seems that the mesangial expansion precedes the thickening of the
PBM and that the albuminuria is associated with the widening of the PBM and not with mesangial expansion alone.

The appearance of functional abnormalities in the proximal tubules, as evaluated by means of the urinary secretion of CC16 and lysozyme in transgenic mice older than 4 months of age, supports the idea that the demonstrated albuminuria in younger mice $(<4 \mathrm{mo})$ is due to structural and biochemical changes in the glomeruli and not to tubular damage. Thus, in the present model, overproduction of TGF- $\beta 1$ is accompanied mainly by a glomerular disease. CC16 and lysozyme are very sensitive markers for detection of tubular damage in man and rodents (Bernard et al, 1994; Halatek et al, 1998). CC16 diffuses from its main site of synthesis in the respiratory tract into the circulatory system, whence it is rapidly eliminated by glomerular filtration and then reabsorbed and catabolized in the proximal tubules (Halatek et al, 1998). Lysozyme is mainly produced in the respiratory and gastrointestinal tracts and the lymphoid tissue. After elimination by glomerular filtration, $95 \%$ of the filtered lysozyme is reabsorbed and stored in the proximal tubules (Cojo- 


\section{Extracellular Material per Glomerulus}

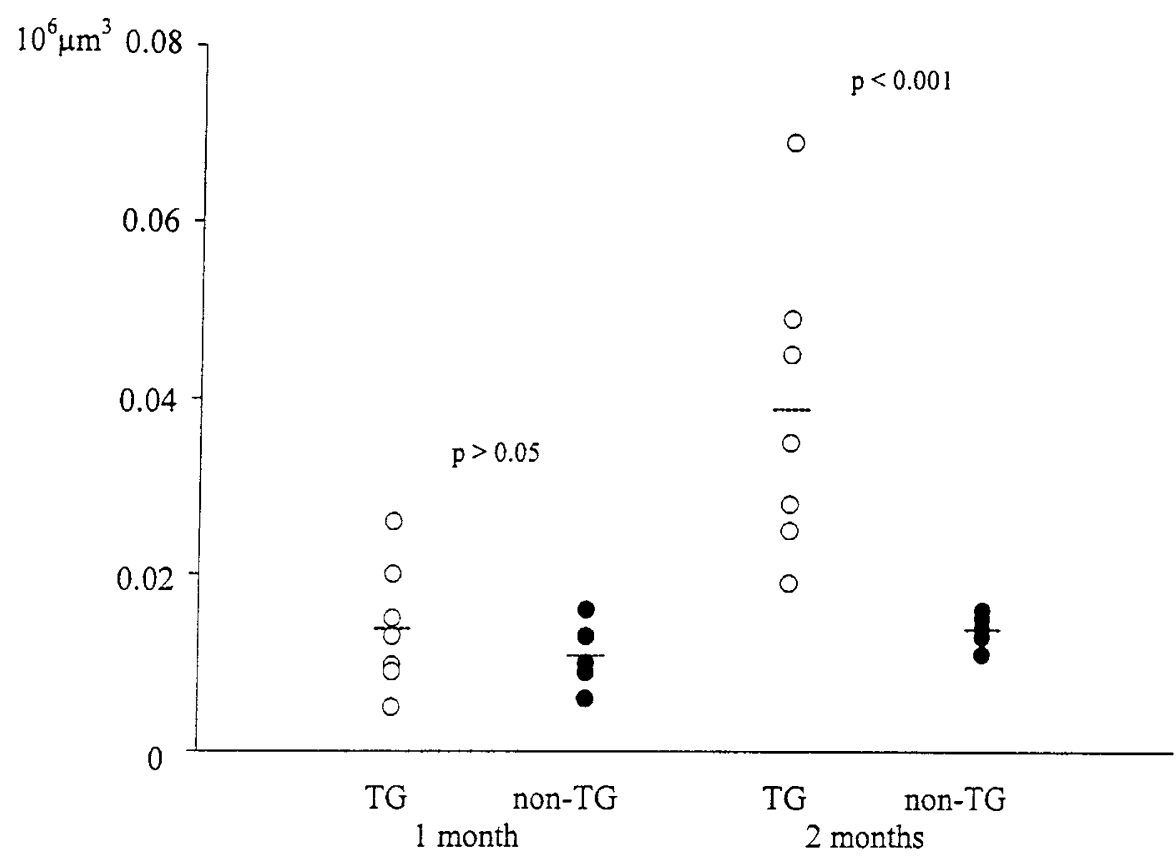

Figure 5.

The amount of extracellular matrix (ECM) per glomerulus (an average of three estimations) in 1- $(n=7)$ and 2-month-old $(n=7)$ transgenic (TG, $\bigcirc)$ and nontransgenic (non-TG, $\bullet$ ) mice.

Table 2. Ultramorphological Parameters in 1- and 2-Month-Old TG and Non-TG Mice ${ }^{a}$

\begin{tabular}{|c|c|c|c|c|c|c|}
\hline & \multicolumn{3}{|c|}{$1 \mathrm{mo}$} & \multicolumn{3}{|c|}{$2 \mathrm{mo}$} \\
\hline & \multicolumn{3}{|c|}{ Non- } & \multicolumn{3}{|c|}{ Non- } \\
\hline & TG & $\mathrm{TG}$ & $p$ & TG & $\mathrm{TG}$ & $p$ \\
\hline$V($ glom $) 10^{6} \mu \mathrm{m}^{3}$ & $\begin{array}{c}0.150 \\
(0.040)\end{array}$ & $\begin{array}{c}0.151 \\
(0.040)\end{array}$ & NS & $\begin{array}{c}0.174 \\
(0.027)\end{array}$ & $\begin{array}{c}0.145 \\
(0.022)\end{array}$ & 0.04 \\
\hline Intra-animal CV in V(G) & $\begin{array}{c}0.48 \\
(0.11)\end{array}$ & $\begin{array}{c}0.37 \\
(0.12)\end{array}$ & NS & $\begin{array}{c}0.31 \\
(0.18)\end{array}$ & $\begin{array}{c}0.30 \\
(0.11)\end{array}$ & NS \\
\hline PBM-surface per glom, $\mathrm{mm}^{2}$ & $\begin{array}{c}0.034 \\
(35)\end{array}$ & $\begin{array}{c}0.037 \\
(21)\end{array}$ & NS & $\begin{array}{c}0.026 \\
(19)\end{array}$ & $\begin{array}{c}0.043 \\
(15)\end{array}$ & 0.0002 \\
\hline BMT nm & $\begin{array}{l}147 \\
(13)\end{array}$ & $\begin{array}{l}131 \\
(8)\end{array}$ & NS & $\begin{array}{l}234 \\
(37)\end{array}$ & $\begin{array}{l}143 \\
(10)\end{array}$ & 0.03 \\
\hline $\mathrm{V}_{\mathrm{v}}(\mathrm{mes} / \mathrm{glom})$ & $\begin{array}{c}0.29 \\
(22)\end{array}$ & $\begin{array}{c}0.22 \\
(22)\end{array}$ & 0.04 & $\begin{array}{c}0.34 \\
(14)\end{array}$ & $\begin{array}{c}0.23 \\
(13)\end{array}$ & 0.0002 \\
\hline $\mathrm{V}_{\mathrm{v}}($ matrix/glom $)$ & $\begin{array}{c}0.08 \\
(47)\end{array}$ & $\begin{array}{c}0.04 \\
(33)\end{array}$ & 0.05 & $\begin{array}{c}0.17 \\
(36)\end{array}$ & $\begin{array}{c}0.05 \\
(15)\end{array}$ & 0.003 \\
\hline Mes surface/tuft surface, \% & $\begin{array}{l}35 \\
(21)\end{array}$ & $\begin{array}{c}28 \\
(15)\end{array}$ & 0.03 & $\begin{array}{c}53 \\
(14)\end{array}$ & $\begin{array}{c}30 \\
(15)\end{array}$ & $<10^{-4}$ \\
\hline
\end{tabular}

${ }^{a} \mathrm{~N}=7$ in each tested group. The glomerular volume $\mathrm{V}(\mathrm{glom})$ was measured for 10-14 glomeruli per animal. In the second row of the table the mean of the intra-individual coefficient of variation for the $V(\mathrm{glom})$ is given. The surface of the peripheral basement membrane (PBM) per glomerulus, the basement membrane thickness (BMT), the volume of mesangium $\left(V_{v}[\mathrm{mes} / \mathrm{glom}]\right)$, matrix $\left(\mathrm{V}_{\mathrm{v}}[\mathrm{matrix} / \mathrm{glom}]\right)$ per glomerulus, and the percentage of the mesangial-urinary interface in relation to the total tuft surface (mes surface/tuft surface, \%) were estimated for three glomeruli from each mouse. All values are mean. The coefficient of variation is given in parentheses. NS, not significant.

cel and Baumann 1983; McClelland and van Furth 1975). Thus, in situations with tubular damage, filtered lysozyme and CC16 may not be reabsorbed or may leak from the proximal tubular cells, and thus they appear in the urine (Bernard et al, 1994; Kabanda et al, 1995). The damage of the proximal tubules may be secondary to the glomerular lesions, probably caused by a decreased availability of oxygen, cytokines, or damage induced by toxic effects of the albuminuria (proteinuria).

At the age of 3 months, the GFR in the transgenic mice was approximately $45 \%$ of the normal, and the 

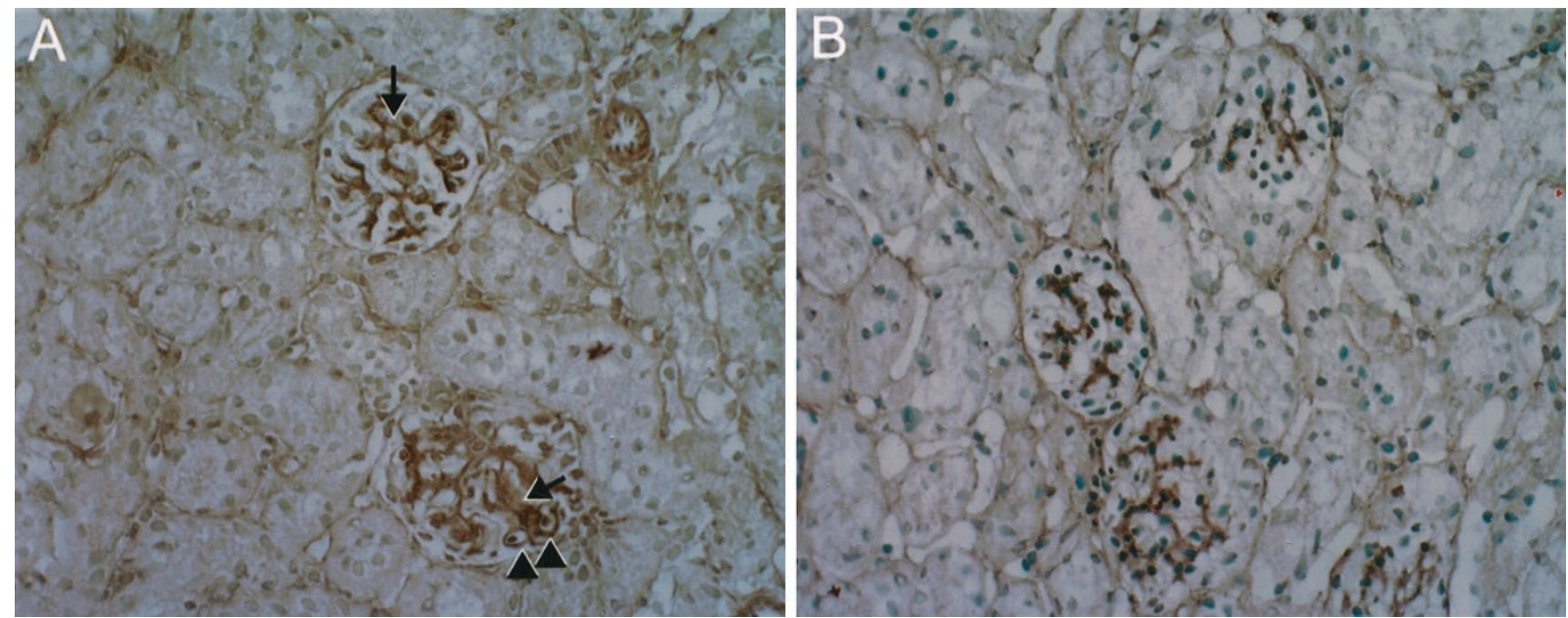

\section{Figure 6 .}

Immunohistochemistry showing the presence of increased amounts of plasminogen-activator-inhibitor (PAI) in the mesangium $(\rightarrow)$ and the peripheral basement membrane $(\mathrm{PBM})(\mathbf{\Delta})$ in a 6-week-old transgenic mouse $(A)(\times 400)$. PAl-1 expression in a 6-week-old nontransgenic animal $(B)(\times 400)$.

glomerular ultramorphology was so anomalous that accurate quantitations of the PBM surface, basement membrane thickness (BMT), $V_{v}$ (mes/glom), and $\mathrm{V}_{\mathrm{v}}$ (matrix/glom) were difficult. Interestingly, at this age the glomeruli of the transgenic mice occupy $2.6 \pm$ $0.2 \%$ of the kidney volume $(n=7)$ compared with 1.4 $\pm 0.1 \%$ in the nontransgenic animals $(n=7)(p<$ 0.01 ), despite a decreased kidney weight/BW ratio (Wogensen et al, 1999). The data suggests that the transgenic mice develop larger glomeruli than their negative littermates at the expense of renal tubules and interstitial tissue. Mesangial expansion may lead to a reduction in the filtration barrier, and to maintain a normal filtration surface, the glomeruli may increase in size (Steffes et al, 1989). Because the decrease in GFR was very modest from 2 to 3 months of age, despite a dramatic deterioration in the morphology of the tuft in the same period, the compensatory mechanisms could play a role. Lack of sufficient compensatory mechanisms in a subset of the transgenic mice may explain why approximately $10 \%$ of the mice die at 2 to 5.5 months of age.

The mechanism of the altered glomerular ECM metabolism in the transgenic mice is partly explained by TGF- $\beta 1$-induced production of PAI- 1 , which facilitates the accumulation of ECM. Our observation and the discovery of increased levels of PAl-1 in the glomeruli of both animals and humans with glomerular diseases such as diabetic nephropathy that are known to be associated with the accumulation of TGF- $\beta 1$ and ECM (Yamamoto et al, 1996) support the notion that TGF- $\beta 1$-induced alterations in the plasminogen activator pathway play a key role in the development of ESRD (Border et al, 1996). Thus, PAl-1 and the plasminogen activator pathway may be targets for new intervention strategies aimed at inhibiting the development of ESRD. This is currently under investigation by breeding the TGF- $\beta 1$ transgenic mice with PAI-1 gene-deficient mice (Carmeliet et al, 1993).

In the cells of the collecting ducts, the apicallocated AQP2 is considered to constitute the func- tional pool of the water channels (Nielsen et al, 1995; Yamamoto et al, 1995). In the presence of vasopressin-resistant hypotonic polyuria, we found a normal, or even stimulated, AQP2 expression within the apical membrane of the cells lining the collecting ducts. These observations and the accumulation of collagen Type I RNA and protein in the inner medulla, detectable at the same age as that at which the concentrating defect appears, support the idea that the impaired water reabsorption is caused by the abnormal accumulation of interstitial ECM, changing the condition for the countercurrent mechanism. This is similar to observations in man, thus indicating the presence of a reduced water uptake in the distal nephron in patients with mild to moderate chronic renal failure resulting from glomerular diseases (Conte et al, 1985). In the present model, TGF- $\beta 1$ from the JGA is filtered into the glomerulus, partly reabsorbed by pinocytosis in the proximal tubules, and partly transported along the tubules inducing endogenous TGF- $\beta 1$ production in the collecting duct in which it is located in the baso-lateral parts of the lining cells (Wogensen et al, 1999). TGF- $\beta 1$ in this location may induce the surrounding interstitial fibroblasts cells to produce collagen Type I. Because several human glomerular diseases are accompanied by increased glomerular levels of TGF- $\beta 1$, we propose that glomerular TGF- $\beta 1$ may have the same fate in man, thereby inducing medullary damage and reduced water permeability in the distal nephron as described by Conte et al (1985), Yamamoto et al (1993, 1996), and Yoshioka et al (1993).

Ultrastructural changes in the kidney of mice with localized overproduction or high circulating levels of TGF- $\beta 1$ have been investigated previously (Kopp et al, 1996; Wogensen et al, 1999). However, neither of the groups performed any quantitation or chronological characterization of the ultrastructural changes. The mice with high circulating levels of TGF- $\beta 1$, driven by the albumin promoter, exhibit increased plasma BUN and increased urinary excretion of protein and 
$\mathrm{N}$-acetylglucosaminidase. The latter two parameters were measured on spot collections of urine because 24-hour urine sampling was not performed (Kopp et al, 1996). In these mice, signs of tubular damage seem to coincide with the appearance of glomerular abnormalities (Kopp et al, 1996), whereas our mice have a preferential glomerular disease. This difference may be explained by the presence of higher levels of TGF- $\beta 1$ in the blood or the induction of other factors in remote organs, potentiating the development of kidney disease. A third type of TGF- $\beta 1$ transgenic mice, in which the TGF- $\beta 1$ production is controlled by the phosphoenolpyruvate carboxykinase (PEPCK) promoter, has primarily tubulointerstitial fibrosis (Kopp, 1999). The glomerulosclerosis observed in these mice occurs as a consequence of either tubular damage and interstitial fibrosis or circulating TGF- $\beta 1$ (Clouthier et al, 1997). However, the glomerular ultrastructure was not assessed by quantitative ultramorphology (Kopp, 1999).

In conclusion, (a) TGF- $\beta 1$-induced reduction in GFR is associated with decreased filtration surface, (b) TGF- $\beta 1$-induced albuminuria is associated with widening of the PBM, (c) expansion of the mesangial volume seems to precede the widening of the PBM, (d) TGF- $\beta 1$-induced deposits of glomerular ECM is partly explained by increased PAl-1 expression, and (e) decreased concentrating ability and polyuria resulting from deposits of ECM in the inner medulla may be early markers for glomerular diseases associated with increased expression of TGF- $\beta 1$ in man. Our observations clearly support the hypothesis that overproduction of, or prolonged exposure to, TGF- $\beta 1$ leads to ESRD. This model will help us to identify new agents that could inhibit the devastating consequences of the overproduction of TGF- $\beta 1$ in the glomeruli.

\section{Materials and Methods}

\section{Mice}

For all experiments we used the previously described TGF- $\beta 1$ transgenic mouse strain expressing mutated porcine TGF- $\beta 1$ under control of the Ren $-1^{\mathrm{C}}$ promoter (Wogensen et al, 1999). Sex- and age-matched nontransgenic littermates were used as control animals. The mice were housed at the animal facility at the University of Aarhus and handled according to the guidelines and procedures recommended by The Animal Experiments Inspectorate, Denmark. They were kept at $21^{\circ} \mathrm{C}$ with a 12-hour day/night cycle and were given free access to standard chow and water until the time of the experiments. The project was approved by the Animal Experiments Inspectorate (\#1997-101-13) and the Danish Working Environment Service (\#BK 1994-1531-164).

\section{Determination of Diurnal Water and Food Consumption, Urine Production, Urine Metabolite Excretion, and Plasma $\mathrm{Na}^{+}, \mathrm{K}^{+}$, and Creatinine}

Age- and sex-matched transgenic and nontransgenic mice were placed in individual metabolic cages (the number of mice is given in Table 1). After a habituation period of 24 hours, the mice were weighed (Table 1). After an additional 24 hours (the observation period), we measured the food consumption, the water intake, and the urine production. The latter was sampled and stored at $-20^{\circ} \mathrm{C}$ until analysis. A loss of excreted solutes during the flow to the urine collector was possible. However, washing experiments demonstrated that approximately $85 \%$ of the excreted solutes were collected after a routine sampling. Thus, a systematic error introduced by the sampling procedure seems negligible. The mice were weighed again and anesthetized with Mebumal (90 mg/kg ip) ( $\mathrm{Ny}$ comed, Roskiloe, Denmark). The abdomen was opened, and the left kidney and renal vessels were dissected from the surrounding tissue. The kidney was removed, cut into three pieces, placed in Tissue-Tek $\mathbb{R}$ OTC compound (Sakura, Zoeterwoude, The Netherlands), and snap frozen in liquid nitrogen. The blood was collected in heparinized glass capillaries (Radiometer, Copenhagen, Denmark) and kept at $4^{\circ} \mathrm{C}$ until centrifugation. The plasma was stored at $-20^{\circ} \mathrm{C}$ until analysis. The right kidney was removed and fixed in $4 \%$ phosphate-buffered paraformaldehyde for the evaluation of the phenotype on PAS (periodic acid Schiff)-stained paraffin sections. Finally, the mice were killed by cervical dislocation. The 24-hour excretion of $\mathrm{Na}^{+}$and $\mathrm{K}^{+}$in the urine was determined by a COBAS $\AA$ integrated analyser (Roche, Basel, Switzerland) at the Department of Clinical Biochemistry, Aarhus Kommunehospital, Aarhus, Denmark. The 24-hour urinary albumin excretion (UAE) was determined by radio-immunoassay as previously described using rat antibody and standards (Rasch and Mogensen, 1980). Rabbit antirat albumin antibody was purchased from Nordic Pharmaceuticals and Diagnostics (Tilburg, The Netherlands). For standard and iodination, a globulinfree rat albumin was obtained from Sigma Chemicals (St Louis, Missouri). The detection limit of the assay was defined as the lowest standard $(0.039 \mu \mathrm{g} / \mathrm{ml})$. The concentration of CC16 in the urine was measured using a sensitive immunoassay relying on the agglutination of latex particles coated with polyclonal antirat CC16 antibodies cross-reacting with mouse CC16 (Halatek et al, 1998). The detection limit of the assay was $0.5 \mu \mathrm{g} / \mathrm{l}$, and the recovery was $90 \pm 7 \%$ (Halatek et al, 1998). Inter- and intra-assay variations range from $5 \%$ to $10 \%$. The concentration of urinary lysozyme was determined by a similar latex agglutination assay (Bernard and Lauwerys, 1983). The assay employs rabbit antibodies raised against lysozyme purified from the urine of rats suffering from toxic tubulopathy. The antibody cross-reacts with mouse lysozyme. The detection limit of the assay is $0.15 \mu \mathrm{g} / \mathrm{l}$, and the inter- and intra-assay variations are 10\% (all information on the lysozyme assay is given as personal communication by $\mathrm{C}$. Hermans). The plasma concentrations of $\mathrm{Na}^{+}, \mathrm{K}^{+}$, creatinine, and BUN were measured with standard methods at the Department of Clinical Biochemistry, Skejby Hospital, Aarhus, Denmark, using a VITROS $950 \AA$ integrated analyser (Johnson and Johnson, New Brunswick, New Jersey). 
It was difficult to obtain sufficient amounts of urine and plasma from some of the mice included in Table 1. Therefore, the biochemical data of these animals are presented as an age- and sex-matched subpopulation (Table 3). Furthermore, it was necessary to mix equal amounts of plasma from two 1-month-old transgenic mice and four 6-week-old nontransgenic mice, respectively, to get enough material for the blood analyses (the urine from the same mice was analyzed separately).

\section{${ }^{51}$ Cr-EDTA Clearance}

To evaluate the glomerular function, we determined the ${ }^{51} \mathrm{Cr}$-EDTA clearance according to Hackbarth and Lunebrink (1979), with minor adjustments. In short, 80 $\mu$ l blood was taken from the retrobulbar plexus $(\mathrm{t}=0)$ of 3-month-old, randomly chosen, transgenic $(n=7)$ $(22 \pm 1.1 \mathrm{~g})$ and nontransgenic $(n=5)(26 \pm 1.6 \mathrm{~g})$ mice. This was followed by injection into a tail vein of approximately $6 \mu \mathrm{Ci}$ of ${ }^{51} \mathrm{Cr}$-EDTA corresponding to $1.32 \times 10^{6} \mathrm{cpm} / 20 \mathrm{~g}$ as determined by registration of $\gamma$-activity $\left(\mathrm{A}_{\mathrm{i}}\right)$. Blood $(80 \mu \mathrm{l})$ was sampled 10, 20, 30, 40 , and 50 minutes after injection and counted with a $\gamma$-counter. The amount of counts per $\mathrm{ml}$ of plasma was calculated using the hematocrit value, which was determined from the sample taken at $\mathrm{t}=0$. The logarithm of the plasma activity was plotted against time and a linear regression analysis was performed. The elimination constant $(\mathrm{k})$ and the initial plasma activity $\left(A_{0}\right)$ were calculated as the slope of the line of regression and as the intercept with the $y$-axis, respectively. Finally, the ${ }^{51} \mathrm{Cr}$-EDTA clearance $\left(k \times A_{i} /\right.$ $\left.A_{o}\right) / S\left(S=10^{2 / 3 B W}\right)$ and the distribution volume $\left(A_{i} / A_{o}\right)$ $\times$ 100/BW were calculated.

\section{Plasma Concentration of Aldosterone}

Age- and sex-matched transgenic and nontransgenic mice $(4,6$, and 8 weeks old and 3 and 5 months old)

Table 3. Number of Mice Used for Determination of Biochemical Parameters ${ }^{a}$

\begin{tabular}{cccccc}
\hline & \multicolumn{2}{c}{ Blood analysis } & & \multicolumn{2}{c}{ Urine analysis } \\
\cline { 2 - 3 } \cline { 5 - 6 } Age & TG & Non-TG & & TG & Non-TG \\
$(\mathrm{mo})$ & $n(\mathrm{M} / \mathrm{F})$ & $n(\mathrm{M} / \mathrm{F})$ & & $n(\mathrm{M} / \mathrm{F})$ & $n(\mathrm{M} / \mathrm{F})$ \\
\hline 1 & 5 & 5 & & 6 & 5 \\
& $\left(3 / 2^{*}\right)$ & $(3 / 2)$ & & $(3 / 3)$ & $(3 / 2)$ \\
$11 / 2$ & 6 & 6 & & 6 & 8 \\
& $(3 / 3)$ & $\left(3 / 3^{*}\right)$ & & $(3 / 3)$ & $(4 / 4)$ \\
2 & 6 & 6 & & 6 & 6 \\
& $(2 / 4)$ & $(2 / 4)$ & & $(2 / 4)$ & $(2 / 4)$ \\
3 & 6 & 6 & & 6 & 6 \\
& $(3 / 3)$ & $(3 / 3)$ & & $(3 / 3)$ & $(3 / 3)$ \\
4 & 6 & 6 & & 6 & 6 \\
& $(0 / 6)$ & $(0 / 6)$ & & $(0 / 6)$ & $(0 / 6)$ \\
5 & 6 & 6 & & 6 & 6 \\
& $(2 / 4)$ & $(2 / 4)$ & & $(2 / 4)$ & $(2 / 4)$ \\
\hline
\end{tabular}

\footnotetext{
${ }^{a}$ The numbers in parentheses are the number of males $(\mathrm{M})$ and females $(\mathrm{F})$ at the given age. ${ }^{*}$ Indicates pooled plasma samples.
}

were randomly selected for the experiment $(n=6$ in each group at each sampling point). Blood was taken from the retrobulbar plexus in heparinized tubes (Radiometer) and centrifuged, and the plasma was stored at $-20^{\circ} \mathrm{C}$ until the time of assay. The plasma aldosterone concentration was measured by a commercially available RIA kit (Coat-a-Count $\AA$; Diagnostic Products Corporation, Los Angeles, California) according to the supplier's instructions. Data are presented as an average of the results obtained from analyses of plasma diluted $1: 2$ and 1:4, although in some cases there was only enough plasma available for one dilution. According to the manufacturer the detection limit of the assay was $16 \mathrm{pg} / \mathrm{ml}$, and the inter- and intra-assay variations in the relevant levels were $3.9 \%$ to $8.1 \%$ and $2.7 \%$ to $4.0 \%$, respectively.

\section{Urine Concentrating Ability}

Spot urine samples were collected from 6- $(n=6)$ and 12- $(n=8)$ week-old transgenic mice and agematched nontransgenic littermates, $n=2$ and $n=13$, respectively. The randomly chosen animals were placed without access to food and water in individual cages, and after 12 hours a new sample of urine was collected. Unfortunately, it was impossible to waterdeprive the mice longer than 12 hours because the transgenic animals died. The urine osmolarity was measured using an osmometer (Osmomat 030-D; Gonotec, Berlin, Germany) at the Department of Clinical Physiology, Skejby Hospital, Aarhus, Denmark.

\section{Freewater Clearance}

Three-month-old transgenic $(n=6)$ and nontransgenic $(n=4)$ mice were placed in individual metabolic cages with free access to water and chow. At the end of the observation period, blood was drawn from the retrobulbar plexus. Urine and plasma osmolarity were measured as described above and the freewater clearance (urine volume per unit time $\times$ (1-urine osmolarity/plasma osmolarity) was calculated.

\section{Immunohistochemistry (IHC)}

Paraffin sections or cryo-sections (5- $\mu \mathrm{m}$ thick) were stained by standard methods. Briefly, the cryosections were fixed in acetone $\left(-20^{\circ} \mathrm{C}, 10\right.$ minutes), blocked with $2 \%$ normal serum, and incubated for 30 minutes at room temperature with the primary antibody followed by incubation for 30 minutes with the relevant biotinylated secondary antibody. Endogenous peroxidase was blocked with $1 \%$ hydrogen peroxide in methanol. The biotinylated antibodies were labeled with avidin-horseradish peroxidase complexes using an ABC-kit (Vector Laboratories, Burlingame, California). The peroxidase was visualized with 3.3 Diaminobenzidine (Sigma), and the slides were contrasted using $1.5 \%$ methylgreen. Finally, the slides were dehydrated and mounted. We used the following polyclonal antibodies against fibronectin (antimouse, 1:400) (Biogenesis Ltd., Poole, United Kingdom), collagen Types I (antimouse, 1:300) (Biodesign, Kenneb- 
unk, Maine), III (antibovine/antihuman, 1:15) (Chemicon International, Inc., Temecula, California), and V (antirat, 1:100) (Biodesign), and finally, PAl-1 (antirat, 1:15) (American Diagnostica, Greenwich, Connecticut). For the detection of collagen, Type I paraffin sections were deparaffinized, rehydrated, incubated with $0.02 \mathrm{M}$ glycine $\left(20^{\circ} \mathrm{C}, 30\right.$ minutes $)$, and permeabilized with $0.125 \%$ trypsin $\left(37^{\circ} \mathrm{C}, 10\right.$ minutes). All sections were coded and evaluated by a blinded observer. For the evaluation of collagen Type I expression, we examined whether or not it was present in the inner medullar, whereas for PAl-1 the staining extent in the glomeruli was scored as follows: 0 (none), 1, 2, 3, and 4. For the detection of AQP2 by immunofluorescence, we used a polyclonal goat antihuman AQP2 (1:75) (Santa Cruz Biotechnology, Inc., Santa Cruz, California) and a rhodamine-labeled donkey antirabbit IgG (1:175) (Santa Cruz Biotechnology, Inc.).

\section{In Situ Hybridization}

The kidney was fixed overnight in 4\% Na-phosphatebuffered formalin and embedded in paraffin. Deparaffinized sections were deproteinated in proteinase $\mathrm{K}$ $(10 \mu \mathrm{g} / \mathrm{ml})$ for 30 minutes at $20^{\circ} \mathrm{C}$ and prehybridized for 2 to 3 hours at $45^{\circ} \mathrm{C}$ in a buffer composed of $50 \%$ formamide, $0.3 \mathrm{M} \mathrm{NaCl}, 20 \mathrm{~mm}$ tris, $\mathrm{pH} 8.0,5 \mathrm{~mm}$ EDTA, $1 \times$ Denhardt's solution, 10\% dextransulphate, and $10 \mathrm{~mm}$ dithiothreitol (DTT). Hybridization with ${ }^{35} \mathrm{~S}-U T P$-labeled sense or antisense RNA probes $(6 \times$ $10^{5} \mathrm{cpm} /$ section) was done for 16 hours at $50^{\circ} \mathrm{C}$ in a humidified chamber. This was followed by washing, dehydration, and drying. Sections were dipped in KODAK NTB2 emulsion and developed after exposure for 3 and 6 weeks. Sense and antisense RNA probes were prepared by in vitro transcription of linearized plasmid containing cDNA encoding the different ECM components. The cDNA clones were most kindly provided by the following persons: R. Hynes, Center for Cancer Research, Massachusetts Institute of Technology, Cambridge, Massachusetts (fibronectin and fibronectin EIIIA) and H. Eberspaecher, Anderson Cancer Center, The University of Texas, Houston, Texas (collagen Types I [ $\alpha 1]$ and III [ $\alpha 1]$ ). All sections were coded and evaluated by a blinded observer.

\section{Preparation of Kidney Tissue for Quantitative Morphology}

Four-, eight-, and twelve-week-old transgenic and nontransgenic mice were randomly selected for the experiment ( $n=7$ in each group at each sampling point). Immediately after the mice were killed by cervical dislocation, a kidney was removed from each mouse, decapsulated, and immersed in fixative (formaldehyde 3\%, glutaraldehyde 1\% in modified Tyrode buffer). After 6 to 7 days fixation, the kidney was cut into slices of $0.5-\mathrm{mm}$ thickness with a set of fixed razor blades. Tissue blocks were punched out of the cortical part of the slaps, thus providing a sample with a uniform distribution from the kidney cortex. The blocks were dehydrated and embedded into epon.

\section{Sectioning for Light and Electron Microscopy}

The blocks were systematically sectioned with $1 \mu \mathrm{m}$ thick sections for the determination of glomerular volume and for the identification of glomeruli for electron microscopy. Thin sections were prepared from three glomeruli in each animal from at least two different blocks of tissue. The thin sections were cut at predetermined central levels.

\section{Estimation of Glomerular Volume}

The volume of each glomerulus (V[glom]) was estimated with Cavalieri's method for glomeruli that appeared in the tissue blocks as the sectioning proceeded, ie, they were sampled independently of size and structure (Østerby et al, 1997). The areas of glomerular profiles with $5-\mu \mathrm{m}$ intervals were measured by point counting in a light microscope transmitting the visual fields to a computer screen at a magnification of $1500 \times$. The volume of an individual glomerulus is then $\mathrm{V}$ (glom) $=\mathrm{t} \times \Sigma \mathrm{A}$ where $\mathrm{t}$ is distance between the levels and $A$ is the area of profiles. The true distance between levels was measured as previously described in detail (Østerby et al, 1997). An average of 12 glomeruli were measured per animal (range, 10-14).

\section{Electron Microscopy}

We analyzed three glomeruli from each mouse. The thin sectioned glomerular profiles were photographed at different levels of magnification. At low magnification the total area was covered. At higher magnification a subsample of the area was photographed using systematic independent sampling. For the 1-month group, photographic prints were produced from the films, whereas for the 2-month group, the images from the electron microscope were digitalized and transferred to a computer screen for measurements.

\section{Measurements}

Using the photographic prints (1-month group), a photomontage was produced at $4200 \times$ magnification for the estimation by point counting of the glomerular tuft as a fraction of the total glomerular profile. Densities of surfaces were estimated by counting intersections between test lines in the grid and the identified interface. This includes the total tuft surface (ie, the exterior side of PBM and the mesangial surface facing the urinary space) and, separately, the mesangial surface towards the urinary space. The surface density was determined by this equation: $S_{V}=2 \times 1 / L$, where $I$ is the number of intersections and $L$ is the total line length within the reference space, defined as the circumscribed minimal convex polygon (Østerby et al, 1997). On the subsample photographed at higher magnification $(21,900 \times)$, point counting was used to estimate the volume fractions of mesangial space and mesangial matrix: $V_{v}$ (mes/tuft) and $V_{v}$ (matrix/mes). Further, BMT was estimated with the orthogonal intercept method (Hirose et al, 1982). The methods with 
the digitalized system (2-month group) were analogous. At low magnification (6680 $\times$ on the computer screen), the majority of the profile was sampled and was used for estimates of the glomerular tuft as a fraction of the total glomerular profile and the volume fraction of the mesangium per glomerulus $\left(\mathrm{V}_{\mathrm{v}}[\mathrm{mes} /\right.$ glom]) using a 9:1 grid. Further, test lines (12 $\mu \mathrm{m}$ per coarse point) were used for counting intersections with total tuft surface and mesangial surface towards urinary space. At a higher magnification $(26,000 \times$ on the computer screen), a 9:1 grid with a distance between coarse points of $2.7 \mu \mathrm{m}$ was used to estimate volume fractions: $V_{v}$ (matrix/tuft) and $V_{v}(P B M /$ tuft). Finally, the BMT was measured (orthogonal intercepts). Combining low and high magnification electron microscopy, we calculated the following glomerular volume fractions: $\mathrm{V}_{\mathrm{v}}$ (mes/glom) (1-month old mice), mesangial matrix $\left(\mathrm{V}_{\mathrm{v}}[\right.$ matrix/glom $\left.]\right)$, and total extracellular material $\left(\mathrm{V}_{\mathrm{v}}\right.$ [ECM/glom]). Combining these estimates with the mean glomerular volume, the measures of total extracellular material and total surface of PBM per glomerulus were obtained.

\section{Statistical Analysis}

Unless otherwise stated, the data are expressed as mean \pm SEM. The two-tailed Mann-Whitney test was used to analyze differences between transgenic and nontransgenic mice. When considering the effect of one experimental factor on two or more experimental groups, we used the Kruskal-Wallis one-way analysis of variance (ANOVA) on ranks followed by Dunn's multiple comparison test. The Spearman rank order correlation analysis was employed when measuring the strength of association $(r)$ between pairs of variables. Sigma Stat scientific software program (SPSS Science, Chicago, Illinois) was used for the calculations. The level of significance was set at $p<0.05$.

\section{Acknowledgements}

We are indebted to Helga Kirkegaard Olesen, Anita Morell, Lone Lysgaard, Birtha Saugbbjerg, Karin Vestergaard, Mette Degn, and Kirsten Nyborg for their technical assistance and Karin Ørbæk for linguistic assistance. We are grateful to Frederik DagnæsHansen, Department of Microbiology, Aarhus University, Denmark, for help during the ${ }^{51} \mathrm{Cr}$-EDTA clearance experiment. We are especially grateful to our colleagues, Thomas Ledet, Lars Rasmussen, Søren S. Sørensen, and Jørgen Frøkiær, for many inspiring discussions. Finally, we thank the staff at the animal facility, The Bartholin Building, Aarhus University, Denmark, for an excellent collaboration.

\section{References}

Bernard AM and Lauwerys RR (1983). Continuous-flow system for automation of latex immunoassay by particle counting. Clin Chem 29:1007-1011.

Bernard AM, Thielemans NO, and Lauwerys RR (1994). Urinary protein 1 or Clara cell protein: A new sensitive marker of proximal tubular dysfunction. Kidney Int Suppl 47:S34S37.

Border WA and Noble NA (1997). TGF-beta in kidney fibrosis: A target for gene therapy. Kidney Int 51:1388-1396.

Border WA and Ruoslahti E (1992). Transforming growth factor-beta in disease: The dark side of tissue repair. $\mathrm{J}$ Clin Invest 90:1-7.

Border WA, Yamamoto T, and Noble NA (1996). Transforming growth factor beta in diabetic nephropathy. Diabetes Metab Rev 12:309-339.

Bódi I, Kimmel PL, Abraham AA, Svetkey LP, Klotman PE, and Kopp JB (1997). Renal TGF-beta in HIV-associated kidney diseases. Kidney Int 51:1568-1577.

Bruijn JA, Roos A, de Geus B, and de Heer E (1994). Transforming growth factor-beta and the glomerular extracellular matrix in renal pathology. J Lab Clin Med 123:34-47.

Carmeliet P, Kieckens L, Schoonjans L, Ream B, van Nuffelen A, Prendergast G, Cole M, Bronson R, Collen D, and Mulligan RC (1993). Plasminogen activator inhibitor-1 genedeficient mice. I. Generation by homologous recombination and characterization. J Clin Invest 92:2746-2755.

Clouthier DE, Comerford SA, and Hammer RE (1997). Hepatic fibrosis, glomerulosclerosis, and a lipodystrophy-like syndrome in PEPCK-TGF- $\beta 1$ transgenic mice. $\mathrm{J}$ Clin Invest 100:2697-2713.

Coimbra T, Wiggins R, Noh JW, Merritt S, and Phan SH (1991). Transforming growth factor-beta production in antiglomerular basement membrane disease in the rabbit. Am $\mathrm{J}$ Pathol 138:223-234.

Cojocel C and Baumann K (1983). Renal handling of endogenous lysozyme in the rat. Ren Physiol 6:258-265.

Conte G, Dal Canton A, Fuiano G, Terribile M, Sabbatini M, Balletta M, Stanziale P, and Andreucci VE (1985). Mechanism of impaired urinary concentration in chronic primary glomerulonephritis. Kidney Int 27:792-798.

Ellis EN, Steffes MW, Goetz FC, Sutherland DE, and Mauer SM (1986). Glomerular filtration surface in type I diabetes mellitus. Kidney Int 29:889-894.

Fine LG, Orphanides C, and Norman JT (1998). Progressive renal disease: The chronic hypoxia hypothesis. Kidney Int Suppl 65:S74-S78.

Fushimi K, Uchida S, Hara Y, Hirata Y, Marumo F, and Sasaki $S$ (1993). Cloning and expression of apical membrane water channel of rat kidney collecting tubule. Nature 361:549-552.

Hackbarth $\mathrm{H}$ and Lunebrink $\mathrm{J}$ (1979). [Determination of the mouse glomerular filtration rate by total $51 \mathrm{Cr}$-EDTA plasma slope clearance depending on age and sex]. Z Versuchstierkd 21:38-46.

Halatek T, Hermans C, Broeckaert F, Wattiez R, Wiedig M, Toubeau G, Falmagne P, and Bernard A (1998). Quantification of Clara cell protein in rat and mouse biological fluids using a sensitive immunoassay. Eur Respir J 11:726-733.

Hirose K, Østerby R, Nozawa M, and Gundersen HJ (1982). Development of glomerular lesions in experimental long-term diabetes in the rat. Kidney Int 21:889-895.

Hirose K, Tsuchida H, Østerby R, and Gundersen HJ (1980). A strong correlation between glomerular filtration rate and filtration surface in diabetic kidney hyperfunction. Lab Invest 43:434-437. 
Iwano M, Kubo A, Nishino T, Sato H, Nishioka H, Akai $Y$, Kurioka H, Fujii Y, Kanauchi M, Shiiki H, and Dohi K (1996). Quantification of glomerular TGF- $\beta 1$ mRNA in patients with diabetes mellitus. Kidney Int 49:1120-1126.

Kabanda A, Jadoul M, Lauwerys R, Bernard A, and van Ypersele de Strihou (1995). Low molecular weight proteinuria in Chinese herbs nephropathy. Kidney Int 48:1571-1576.

Kopp JB (1999). Glomerulosclerosis, tubulointerstitial fibrosis, and obstructive uropathy in PEPCK-TGF-beta1 transgenic mice. Am J Kidney Dis 34:177-183.

Kopp JB, Factor VM, Mozes M, Nagy P, Sanderson N, Bottinger EP, Klotman PE, and Thorgeirsson SS (1996). Transgenic mice with increased plasma levels of TGF-beta 1 develop progressive renal disease. Lab Invest 74:991-1003.

Ma T, Yang B, Gillespie A, Carlson EJ, Epstein CJ, and Verkman AS (1998). Severely impaired urinary concentrating ability in transgenic mice lacking aquaporin-1 water channels. J Biol Chem 273:4296-4299.

Maisonneuve P, Agodoa LY, Gellert R, Stewart RJH, Buccianti G, Lowenfels AB, Wolfe RA, Jones E, Disney APS, Briggs D, McCredie M, and Boyle P (2000). Distribution of primary renal diseases leading to end-stage renal failure in the United States, Europe, and Australia/New Zealand: Results from an international comparative study. Am J Kidney Dis $35: 157-165$.

McClelland DB and van Furth R (1975). In vitro synthesis of lysozyme by human and mouse tissues and leucocytes. Immunology 28:1099-1114.

Nielsen S, Chou CL, Marples D, Christensen El, Kishore BK, and Knepper MA (1995). Vasopressin increases water permeability of kidney collecting duct by inducing translocation of aquaporin-CD water channels to plasma membrane. Proc Natl Acad Sci USA 92:1013-1017.

Niemir Zl, Stein H, Noronha IL, Krüger C, Andrassy K, Ritz E, and Waldherr R (1995). PDGF and TGF-beta contribute to the natural course of human IgA glomerulonephritis. Kidney Int 48:1530-1541.

Okuda S, Languino LR, Ruoslahti E, and Border WA (1990). Elevated expression of transforming growth factor-beta and proteoglycan production in experimental glomerulonephritis. Possible role in expansion of the mesangial extracellular matrix [published erratum appears in J Clin Invest 86:2175]. $\mathrm{J}$ Clin Invest 86:453-462.

Østerby R, Asplund J, Bangstad HJ, Nyberg G, Rudberg S, Viberti G, and Walker JD (1997). Glomerular volume and the glomerular vascular pole area in patients with insulindependent diabetes mellitus. Virchows Arch 431:351-357.

Østerby R, Parving HH, Nyberg G, Hommel E, Jorgensen HE, Lokkegaard $\mathrm{H}$, and Svalander C (1988). A strong correlation between glomerular filtration rate and filtration surface in diabetic nephropathy. Diabetologia 31:265-270.

Rasch R and Mogensen CE (1980). Urinary excretion of albumin and total protein in normal and streptozotocin diabetic rats. Acta Endocrinol (Copenh) 95:376-381.
Shankland SJ, Scholey JW, Ly H, and Thai K (1994). Expression of transforming growth factor-beta 1 during diabetic renal hypertrophy. Kidney Int 46:430-442.

Sharma K and Ziyadeh FN (1994). Renal hypertrophy is associated with upregulation of TGF-beta 1 gene expression in diabetic BB rat and NOD mouse. Am J Physiol 267:F1094F1101.

Sharma K, Ziyadeh FN, Alzahab B, McGowan TA, Kapoor S, Kurnik BRC, Kurnik PB, and Weisberg LS (1997). Increased renal production of transforming growth factor- $\beta 1$ in patients with type II diabetes. Diabetes 46:854-859.

Steffes MW, Osterby R, Chavers B, and Mauer SM (1989). Mesangial expansion as a central mechanism for loss of kidney function in diabetic patients. Diabetes 38:1077-1081.

Tomooka S, Border WA, Marshall BC, and Noble NA (1992). Glomerular matrix accumulation is linked to inhibition of the plasmin protease system. Kidney Int 42:1462-1469.

Wogensen L, Nielsen CB, Hjorth P, Rasmussen LM, Høj Nielsen A, Gross K, Sarvetnick N, and Ledet T (1999). Under control of the renin-1c promoter, locally produced transforming growth factor- $\beta 1$ induces accumulation of glomerular extracellular matrix in transgenic mice. Diabetes 48:182-192.

Yamamoto T, Nakamura T, Noble NA, Ruoslahti E, and Border WA (1993). Expression of transforming growth factor beta is elevated in human and experimental diabetic nephropathy. Proc Natl Acad Sci USA 90:1814-1818.

Yamamoto T, Noble NA, Cohen AH, Nast CC, Hishida A, Gold LI, and Border WA (1996). Expression of transforming growth factor-beta isoforms in human glomerular diseases. Kidney Int 49:461-469.

Yamamoto T, Noble NA, Miller DE, and Border WA (1994). Sustained expression of TGF-beta 1 underlies development of progressive kidney fibrosis. Kidney Int 45:916-927.

Yamamoto T, Sasaki S, Fushimi K, Ishibashi K, Yaoita E, Kawasaki K, Marumo F, and Kihara I (1995). Vasopressin increases AQP-CD water channel in apical membrane of collecting duct cells in Brattleboro rats. Am J Physiol 268: C1546-C1551.

Yang CW, Hattori M, Vlassara H, He CJ, Carome MA, Yamato E, Elliot S, Striker GE, and Striker LJ (1995). Overexpression of transforming growth factor-beta $1 \mathrm{mRNA}$ is associated with up-regulation of glomerular tenascin and laminin gene expression in nonobese diabetic mice. J Am Soc Nephrol 5:1610-1617.

Yoshioka K, Takemura T, Murakami K, Okada M, Hino S, Miyamoto H, and Maki S (1993). Transforming growth factorbeta protein and mRNA in glomeruli in normal and diseased human kidneys. Lab Invest 68:154-163. 